\title{
Sosialisasi Pemanfaatan Program Corporate Social Responsibility (CSR) bagi Pelaku Usaha Elly Yuliawati ${ }^{1^{*}}$ \\ Program Studi IImu Komunikasi, Fakultas Ilmu Komunikasi, Universitas Mercu Buana
}

Submisi: 15 Juni 2019; Revisi: 05 Maret 2020; Penerimaan: 25 Juni 2020

Keywords:
Corporate social
responsibility
Homestay
Sosialisasi
Pariwisata

Keywords: Corporate social responsibility Homestay Socialization Tourism
Abstract Wisata Pantai Sawarna menawarkan suasana alam yang asri yang berbeda dengan tempat wisata lain di Indonesia. Mengingat jarak lokasi ini dari pusat kota, warga Banten dan Dinas Pariwisata setempat menggagas sebuah homestay yang bisa digunakan untuk bermalam bagi wisatawan lokal maupun mancanegara. Homestay mampu menyediakan tempat untuk melepas penat, tidur nyenyak, makan enak, mandi dan berganti pakaian secukupnya. Oleh karena itu, sarana dan prasarana homestay harus terus dikembangkan dan ditingkatkan sesuai dengan perkembangan zaman. Tujuan dari pengabdian masyarakat ini adalah untuk mengarahkan pemilik usaha homestay dalam menyasar program Corporate Social Responsibility (CSR) dari perusahaan di lingkungan Provinsi Banten untuk mengembangkan usahanya. Dengan menyediakan program CSR, perusahaan dapat berkontribusi secara etis untuk pengembangan lingkungan sosial dan bisnis mereka. Ini bisa menjadi solusi untuk kelangsungan bisnis dan kemitraan strategis yang berkelanjutan. Hasil pelatihan menunjukkan adanya penambahan pengetahuan dan pemahaman, peserta dapat mengetahui tentang CSR dan memanfaatkan peluang dari program CSR perusahaan dalam mengembangkan usahanya, mengetahui tahapan dan strategi dalam upaya memperoleh pendanaan untuk program CSR, dan yang terpenting ada keinginan untuk mencoba memanfaatkan programCSR perusahaan di lingkungan sekitar wilayahnya.

Abstract Abstract Sawarna Beach Tourism offers an atmosphere of beautiful nature that is different from other tourist attractions in Indonesia. Given the distance of this location from the center of the City of Banten residents and the local tourism agency initiated a homestay that can be used to spend the night for local and foreign tourists. The homestay is able to provide a place to unwind, have a good sleep, eat well, take a bath and change clothes adequately. Therefore, facilities and infrastructures of the homestay must continue to be developed and upgraded in accordance with the times. The purpose of this community service is to direct business owners' homestay in targeting Corporate Social Responsibility (CSR) programs from companies in the Banten Province environment to develop their businesses.

\section{PENDAHULUAN}

Pantai Sawarna yang terletak di Kabupaten Lebak, Banten menjadi sa lah sa tu tujuan wisa ta dengan keka yaan alam yang eksotis. Ala m menghiasi pantai ini dengan batu besaryang menyerupai pulau dan menjadi hal unik yang membedakannya dengan wisa ta pantai yang lain. Hasil penelitian (Rahma, Yuliawati, \& Gusfa, 2017) menunjukkan bahwa potensi wisata
Pantai Sawarna belum terpublikasi secara optimal. Usaha-usaha pendukung wisata yang terdapat di sekitarnya, seperti homestay, restoran, dan tempattempat penjualan cendera mata juga mengalami hal yang relatif serupa, padahal masyarakat memiliki potensi besar untuk turut mempromosikan wilayah dan usahanya. Rumah singgah atau yang umum disebut homestay merupakan bagian dari kegiatan usaha di

ISSN 2460-9447 (print), ISSN 2541-5883 (online)

*Corresponding author : Elly Yuliawati

Program Studi Ilmu Komunikasi, Fakultas IImu Komunikasi, Universitas Mercu Buana, JI. Ring Road Utara, Ngropoh, Condongcatur, Depok, Sleman 55281, Daerah Istimewa Yogyakarta

Email: elly_yuliawati@mercubuana.ac.id 
Pantai Sawarna. Sayangnya, pemahaman mengenai pengembangan usaha ini belum dimiliki oleh para pemilik rumah singgah di Pantai Sawarna, Kabupaten Lebak, Banten.

Masyarakat adalah objek sekaligus subjek pembangunan. Bagi korporasi, masyarakat adalah objek kegiatan Corporate Social Resposibility (CSR). Dengan demikian, masyarakat juga memiliki peran penting untuk menyampaikan a spira si yang berkaitan dengan kondisi wilayahnya kepada pemerintah dan pihak swasta. Informasi perihal kebutuhan warga masyarakat di destinasi wisata Pantai Sawama, misalnya, akan memudahkan pihak pemerintah dan swasta dalam melakukan pembangunan yang lebih terarah. Sinergi a ntara pelaku bisnis dengan CSR-nya, pemerintah dengan anggaran serta regula sinya, dan ma syarakat dengan ikhtiar kemandiriannyamenupakan kerja sama tripartite yang ideal da lam membangun bangsa agarmenjadi lebih maju.

Pemahaman mengenai pentingnya pengembangan usaha oleh warga di sekitar Pantai Sawarna sudah saatnya diarahkan pada target yang lebih spesifik. Kegiatan ini mengarahkan peserta untuk membidik program CSR dari perusahaan-perusahaan di lingkungan Provinsi Banten. CSR merupakan konsep moral dan etik, yaitu perusahaan bertanggung jawab secara moral terhadap keadaan sosial di sekitamya. Perusa haan bisa berperan sebagai problem solver bagi sosial kemasyarakatan ataupun kelestarian lingkungan. Isu-isu environmental ethic bisa diterapkan pada berbagai kalangan, termasuk industri karena secara etika, industri/perusahaan telah mengambil sumber daya alam dari lingkungan, minimal udara tempat mereka berada. Program CSR memungkinkan perusahaan untuk berinteraksi dengan stakeholder. Program-program bisa dikreasikan guna menyerap apa yang menjadi keluhan atau masalah bagi warga dan lingkungannya. Dengan melihat kebutuhan warga dan kebutuhan a lam lingkungan, rasa kemanusiaan dan empati perusahaan akan tergugah untuk membantu dengan sukarela (Rahmatullah, 2011). Sebaliknya bagi perusa haan, program CSR yang dibingkai dengan nilai moral dan komitmen kepada stakeholders, akan menghasilkan ja linan hubungan yang konstruktif dan menentukan kesuksesan perusahaan dalam jangka panjang (Ira wan, 2018).

CSR seba gai salah satu instrumen da lam proses community development, memerlukan keterlibatan masyarakat. Peran serta masyarakat menentukan keberhasilan pemberdayaan masyarakat itu sendiri. Dengan demikian setiap tahapan dalam proses pengembangan, mulai dari mengidentifikasi masalah, merencanakan, melaksanakan, memonitor dan menilai keberhasilan perlu melibatkan partisipasi masyarakat (Ife \& Tesoriero, 2006).
Pantai Sa warna Lebak dan sekitarnya menupakan objek wisa ta yang berpotensi menjadi destinasi wisata interna sional. Variasi pantai, la ut, pa sir putih, batuan karang, bukit, hutan lindung, goa, dan pohon kelapa memberikan ga mbaran kompleks ekologi pantai. Jika melihat ke sisi lain pantai, terhampar luas lahan pertanian yang hijau yang sebagian besar belum dimanfaatkan secara intensif, baik kuantitas maupun kua litasnya (Susilowati, 2017).

Beberapa permasalahan di wilayah Pantai Sawa rna yang berhasil diidentifikasi oleh Susilowati (2017) dalam penelitiannya sebagaiberikut. (1) Potensi wilayah desa di sekitar Pantai Sawarna, Kabupaten Lebak belum tergali secara optimal. (2) Bentangan alam desa Sawarna sebagian besar perkebunan, kepadatan penduduk dari rendah hingga sedang, dan mayoritas pendidikannya masih dasar, mata pencaharian umumnya petani dan buruh tani, dan aksesibilitas relatif sedang bahkan cenderung rendah. (3) Pengelolaan fasilitas primer dan sekunder (akomodasi, kuliner, souvenir) serta fasilitas yang tersedia di wilayah setempat (aksesibilitas, parkir, toilet, tempat ibadah) masih terbatas (Susilowati, 2017).

Tren perkembangan pariwisata di dunia saat ini mengarah pada pemanfaatan potensi wisata alam dan wisata pedesaan serta pemanfaatan dalam pengemban gan ekonomimasyarakat. Seperti penelitian (Akda \& Öter, 2011) menganalisis destinasi unggulan pariwisata dunia dari perspektif geografis dan memahami peran geografi dalam proses mobilisasi pengunjung di Turki. Pengelola an wisata alam di kawasan gersang Karoo Afrika Selatan dilakukan dengan mengoptimalkan wisata gurun sebagai daya tarik postmodern (Atkinson, 2016). Kamboja mengembangkan pariwisata pedalaman pedesaan dengan mengadopsi pendekatan mata pencaharian untuk menyelidiki pengaruh tujuan wisa ta utama di nega ra tersebut (Biddulph, 2015).

Di Kenya Barat dilakukan penelitian untuk mencari cara mengintegrasikan pariwisata dengan strategi pembangunan pedesaan dan manfaat yang diha silkan dari in tegra si tersebut dalam jangka panjang bagi masyarakat lokal (Obonyo \& Fwaya, 2014). Indonesia juga mengembangkan prakarsa wisata pedesaan berbasis masyarakat, yaitu mengembangkan kegia tan pariwisa ta pada aspek budaya dan dampaknya terha dap pelestarian budaya (Fatimah, 2015).

Kekayaan a lam, keanekaragaman budaya, dan kekhasan pedesaan Indonesia menjadi daya tarik unggulan untuk mengundang pelancong dari berbagai negeri. Sayangnya, potensi objek wisa ta tersebut belum dikelola secara maksimal (Zakaria \& Suprihardjo, 2014), belum dikembangkan, dan dimanfaatkan sebagai industri andalan dalam meningkatkan 
pendapatan daerah (Susilowati, 2017). Terkait hal tersebut, permasalahan da lam pengabdian ini adalah potensi wilayah Pantai Sa warna di Kabupaten Lebak yang belum tergali secara optimal.

Berdasarkan mata pencaharian, dari 1343 jumlah penduduk di Kabupaten Lebak, sebanyak 926 orang sebagai petani dan 130 orang menjadi buruh tani (Badan Pusat Statistik Kabupaten Lebak, 2018). Ada pun tingkat pendidikan penduduk bervariasi, yaitu $33.6 \%$ tamat SMP, $1.4 \%$ merupakan lulusan SMA, $3.5 \%$ berpendidikan tinggi (diploma dan sa rjana), dan $31.2 \%$ tidak tamat SMP dan SMA (Dinas Pariwisata ProvinsiBanten, 2017)

Pengamatan terhadap fasilitas primer dan sekunder di wilayah Pantai Sawarna, seperti akomodasi, kuliner, souvenir, dan fasilitas pendukung yang tersedia di sa na, seperti a ksesibilitas, parkir, toilet, dan tempat ibadah masih terbatas pada pemenuhan standar minimum. Sa lah satu faktor disebabkan oleh terbatasnya kemampuan dalammengelola sumber daya dan juga kemampuan ekonomi para pelaku usaha. Sela in itu, berkunjung ke Pantai Sawama tidak mudah ka rena badan jalan yang sela lu rusak akibat la lu lalang kendaraan besar (truk) dan angkutan umum yang jarang mela lui jalan ini. Peristiwa tsunami pada Desember 2018 yang melanda beberapa ba gian di Selat Sunda menyebabkan kunjungan wisatawan menurun. Dampak tersebut sangat dirasakan oleh para pengusaha, khususnya pemilik homestay di daerah pariwisata Pantai Sa warna (Kabar Banten, 2018; Liputan 6, 2018; Tim Pikiran Rakyat, 2019). Berdasarkan permasalahan di atas, pengembangan sumber daya manusia untuk mengelola wisata pantai perlu dilakukan. Warga sebagai pela ku usa ha pendukung objek wisa ta pantai perlu mendapat wawasan a gar dapat melihat peluang usaha. Perusahaan-perusahaan besar, seperti PT Cemindo Gemilang (Semen Merah Putih), PT Global Footwear (perusahaan yang memproduksisandal), dan PT Harendong Organix Tea Estate merupakan sumber yang dapat dimanfaatkan oleh para pemilik usaha pariwisa ta diPantai Sa warna.

Program CSR perusahaan adalah salah satu sumberyang disarankan untuk dibidik oleh warga guna mengga irahkan usaha wisa ta. Warga dilatih membuat proposal yang bisa diajukan kepada perusahaan yang menyiapkan program CSR. Pelatihan komunikasi interpersonal, antarbudaya, media sosial, dan manajemen pengembangan usaha telah diberikan kepa da para pelaku usaha di Pesisir Pantai Sa warna.

Pemaparan kondisi faktual di a tas bertujuan untuk menarik benang merah a ntara kebutuhan peningkatan potensi wisa ta Pantai Sa warna, sumber daya manusia, dan CSR perusahaan. Pengembangan sumber daya manusia juga diarahkan pada industri kreatif yang relevan, seperti cendera mata, buah tangan, rumah makan, homestay, dan transportasi. Semua hal tersebut membutuhkan perhatian dan solusi untuk mempersiapkan peningkatan pemahaman dan kompetensi khalayak sasaran perihal industri kreatif yang relevan dengan kebutuhan masyarakat, khususnya di wilayah pesisir. Program pengabdian kepada masyarakat ini bertujuan agar wa rga di tempat wisata Desa Sa warna ini bisa mengembangkan softskill guna memanfaatkan sumber daya yang ada di lingkungannya, termasuk pemanfaatan CSR dari perusa haan yang a da di lingkungan Provinsi Banten.

\section{METODE}

Target sosialisa si dalam kegiatan ini a dalah para pelaku usaha pendukung objek wisa ta pantai yang tergabung da lam kelompok sadar wisata. Tiga belas peserta yang mengikuti kegia tan inimerupakan pelaku usaha rumah singgah/homestay. Pelaksanaan kegiatan bertempat di Adrew Homestay, Desa Sawarna, yang merupakan sa lah satu rumah singgah yang dikelola oleh peserta. Para pelaku usaha di Pantai Sawarna dalam kesehariannya tidak dekat dengan birokrasi pemerintahan ataupun struktur perusahaan swasta sehingga memerlukan panduan dan pendampingan dalam memahami CSR serta pengajuan dan pemanfaatannya. Metode pelatihan/workshop pemanfaatan program CSR perusahaan merupakan metode terbaik yang dapat digunakan untuk memandu setiap peserta agar dapatmemahami dan melaksanakan materipelatihan.

Materi sosialisasi disampaikan dengan memadukan metode presentasi, dia log dan konsultasi. Metode ini digunakan agar peserta mudah memahami materi yang disampaikan, yaitu perihal CSR, peraturan pemerintah tentang kewajiban perusahaan untuk melaksanakan CSR, dan penyusunan proposal CSR. Materi tentang komunikasi interpersonal, komunikasi antarbudaya, dan media sosial juga disampakan untuk menambah keterampilan pelayanan prima dalam pengelolaan jasa homestay.

Tanya jawab dilakukan untuk mengetahui tingkat pemahaman peserta dan hambatan-hambatan yang dialami peserta dalam memahami materi. Selain itu, dilakukan diskusi dan simulasi guna membangun kesepahaman serta interaksi antarpeserta, menyusun proposal secara berkelompok, audit lingkungan dalam bahasa yang sederhana, dan inventarisasi kebutuhankebutuhan pengelola jasa homestay yang perlu diajukan dalam proposal. 
Eva luasi keberhasilan program dilakukan melalui pre-test dan post-test untuk mendapatkan gambaran pengetahuan serta pemahaman setelah mengikuti kegia tan pela tihan. Sela in itu, dilakukan observasi untuk mengevaluasi keterampilan peserta saat simulasi menyusun proposal pendanaan serta simulasi komunikasi ketika memberikan pelayanan dan menggunakan media sosial sebagai alat promosi. Wawancara juga dilakukan untuk mendapatkan informasi tentang penyelenggaraan kegiatan dan harapan peserta. Proses evaluasi berlangsung secara simultan selama pelaksanaan dan setelah kegiatan selesai. Proses tahapan kegiatan digambarkan dalam Gambar 1 berikutini:

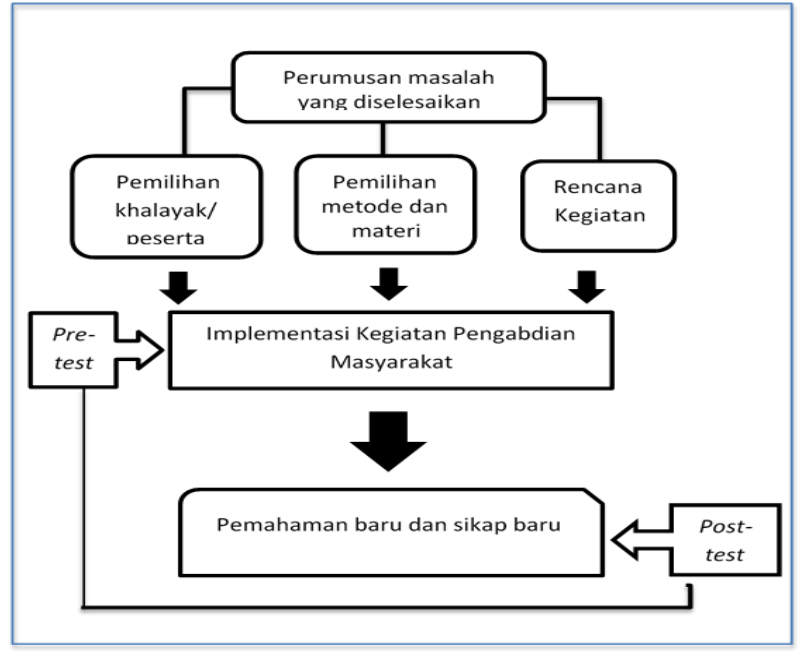

Gambar 1 Alur pelaksanaan kegiatan

Tahapan pelaksanaan kegiatan yang pertama adalah merumuskan masalah yang akan diselesaikan. Pelaksana memulai kegiatan dengan melakukan riset untuk mengetahui permasalahan, kendala, dan kebutuhan masyarakat. Hasil riset pendahuluan menemukan bahwa potensi wisata Sawarna belum terpublikasi secara optimal. Fasilitas pelayanan homestay secara umum hanya sebatas pemenuhan standar minimal, bahkan beberapa tidak memenuhi standar. Haltersebut disebabkan keterbatasandana yang dimiliki pengelola homestay. Tsunami yang melanda beberapa bagian wila yah di Selat Sunda pada Desember 2018 mengakibatkan jumlah kunjungan wisatawan menurun.

Tahap kedua yang merupakan rangkaian perencanaan diawali dengan menentukan khalayak sasaran yang dituju, yaitu 13 orang pelaku usaha homestay. Langkah selanjutnya adalah pemilihan metode yang unik dan kreatif serta penyampaian materi yang mudah dipahami oleh peserta. Langkah berikutnya adalah membuat rancangan kegiatan pelatihan pemanfaatan CSR perusahaan, penggunaan metode presentasi, dialog, konsultasi, dan pendekatan komunikasi persuasif untuk membangun kedekatan dengan peserta.

Tahap ketiga adalah pelaksanaan pre-test yang diikuti oleh seluruh peserta (13 pelaku usaha homestay). Pre-test dilaksanakan selama 30 menit sebelum ceramah dimulai. Pre-test dilakukan dengan dialog santai untuk mendapatkan informasi a wal yang terkait dengan tingkat pengetahuan peserta tentang CSR dan pemanfaatannya. Langkah selanjutnya adalah menyiapkan peserta, memfokuskan perhatian peserta, dan membangun kesediaan komunikasi terbuka. Dalam dia log ini, pelaksana menggali hal-hal yang diketahui oleh peserta tentang CSR, termasuk a pakah peserta mengetahui perihal program CSR yang dilakukan perusahaan di sekitar wilayah mereka dan harapanharapan peserta dalam mengembangkan usaha dan lingkungannya. Berdasarkan dialog santai tersebut diketahui bahwa peserta belum mengetahui perihal CSR, perihal tanggung jawab sosial perusahaan, dan perihal keberadaan perusahaan-perusahaan di wila yahnya.

Tahap keempat a dalah rangkaian sosia lisasi dan pela tihan kegiatan yang dilaksanakan pada 31 Januari 2019. Tahap ini diha diri oleh tiga belas peserta, pemilik usaha homestaydan usaha pendukungnya seperti usaha wa rung makanan dan sembako. Sosialisa si tentang CSR dan pemanfaatannya meliputi aturan pemerintah, penerapan etika dan kewajiban perusahaan temadap lingkungan, membangun kesadaran bersama agar orang mau berkunjung ke Pantai Sawarna, baik pribadi maupun korporasi, dengan memanfaatkan media sosial untuk promosi wisa ta dan pengembangan usaha.

Tahap kelima a dalah menganalisis hasil kegiatan pelatihan, yaitu tingkat pemahaman dan sikap peserta terhadap kegiatan pengabdian kepada masyarakat. Setelah mengikuti pelatihan, peserta mendapat pemahaman baru tentang CSR dan pemanfaatannya bagi pengembangan usaha serta memahami cara menyusun proposal pendanaan dan lampiran pendukungnya. Selain itu, peserta juga memahami teknik komunikasi efektif dan pemanfaatan media sosial.

Tahap keenam adalah post-test yang dilakukan dengan kuesioner. Post-test bertujuan untuk mengukur pelaksanaan kegia tan, yaitu menganalisis keberhasilan program secara menyeluruh, baik aspek kecukupan informasi yang disajikan, kesesuaian materi dengan kebutuhan peserta, ketepatan metode yang digunakan, kemampuan pelaksana da lam membangun suasana, serta konsultasi yang diberikan dan keberlanjutan progra m. Ana lisis deskriptif kualitatif digunakan untuk menjelaskan proses pelatihan dengan melihat kondisi dan ketercapaian target.

\section{HASIL DAN PEMBAHASAN}

\subsection{Potensi wisata Sawarna dan pemberdayaan masyarakat}

"Daya tarik wisata" adalah segala sesuatu yang memiliki keunikan, kemudahan, dan nilai yang berupa keanekaragaman kekayaan alam, budaya, dan hasil bua tan manusia yang menjadi sa saran a tau kunjungan wisatawan ("Undang-Undang Republik Indonesia Nomor 10. Tahun 2009 Tentang Kepariwisa taan,"n.d.). Tabel 1 berikut memberikan informasi tentang objek dan pesona wisata Desa Sawarna. 
Tabel 1 Pesona wisata Sawarna

\begin{tabular}{|c|c|}
\hline Objek Wisata & Pesona Wisata \\
\hline Wisata Alam & 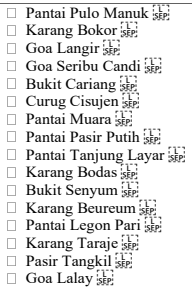 \\
\hline Wisata Budaya & 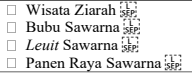 \\
\hline Wisata Buatan & 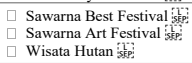 \\
\hline
\end{tabular}

Sumber: (Dinas Pariwisata Provinsi Banten, 2017)

Tabel 1 menunjukkan wisata a lam memiliki pesona terbesar dengan laut dan pantai seba gai objek yang potensinya tidak terbatas. Objek wisata Sawama terbagi menjadi tiga bagian, yaitu wisata alam (beberapa yang menjadi favorit adalah Pantai Pasir Putih, PantaiLegon Pari, Pantai Tanjung Layar, Karang Beureum, Goa Lalay, dan Goa Langir), wisata budaya (wisa ta ziarah, wisa ta bubuikan, wisa ta leuit Sawama, dan wisata panen raya), dan wisata buatan (Sawama Best Festival dan Sa warna Art Festival).

Seba gian besar pesona keindahan pantai Sawama memiliki ga ris pantai memanjang dan bertekstur serta unik seperti pasir yang berwarna putih dan halus(Pantai Pasir Putih), Karang Beureum yang berarti karang berwarna merah, dan batu karang besar yang berdampingan seperti layar di Pantai Tanjung Layar. Secara umum, Desa Sawarna berpotensi besar untuk dikembangkan menjadi desa wisata dengan penguatan pada aspek kelembagaan, peningkatan industri pariwisata, perluasan destinasi dan pengembangan pemasaran pariwisata (Dinas Pariwisata Provinsi Banten, 2017).

Pemberdayaan dapat dimaknai sebagai proses menuju berdaya, proses memperoleh daya, a tau proses pemberia ndaya dari pihak yang memiliki daya kepada pihak yang kurang a tau belum berdaya (Sulistyani \& Wulandari, 2017). Pembahasan tentang pemberdayaan masyarakat mengarah pada tindakan mengubah masyarakat dalam hal kesadaran, pengetahuan, dan keterampilan dari ketiadaan kemampuan menuju terbentuknya kekuatan. Hal ini mensyaratkan keterlibatan masyarakat sebagai faktor pendorong tindakan perubahan. Pengembangan potensi pariwisata pedesaan, seperti mengembangkan infrastruktur, fasilitas, budaya lokal, variasi atraksi, industri kerajinan, wisa ta edukasi, da n kepedulian lingkungan memerlukan partisipasi masyarakat dalam pengelolaannya (Sulistiyani, Aisyah, Mamat, \& Sontang, 2016; Vitasurya, 2016; Zaidan, 2016). Sejalan dengan strategi pengembangan Desa Wisa ta Sawama, kegiatan pemberdayaan masyarakat ini merupakan partisipasi aktif dalam mendukung industri pariwisata di Desa Sawarna, yaitu melalui pengembangan kapabilitas pelaku usaha dan membuka peluang investor dalam memberikan kemudahan akses permodalan bagiusaha mikro.

Program CSR perusahaan sudah diatur secara jelas oleh pemerintah dalam Undang-Undang Nomor 40 Tahun 2007, Pasal 74, yaitu bahwa perseroan yang menjalankan kegiatan usahanya di bidang dan/atau berkaitan dengan sumber daya alam wajib melaksanakan ta nggung ja wab sosial dan lingkungan ("Undang-Undang No. 40 Tahun 2007 Tentang Perseroan Terbatas," n.d.).

Tabel 2 Daftar Perusahaan BUMD di Lingkungan Provinsi Banten

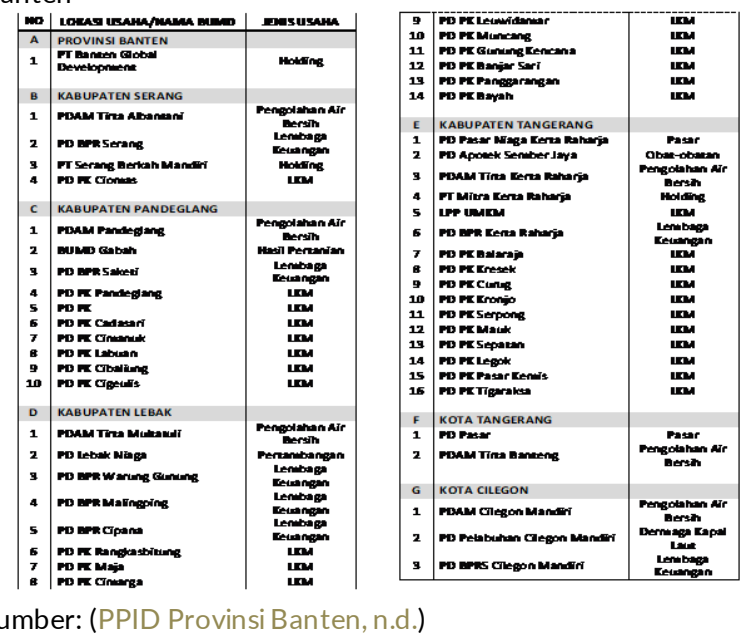

Tabel 2 menunjukkan daftar perusahaan BUMD yang terdapat di lingkungan Provinsi Banten. Di wilayah Kabupaten Lebak terdapat delapan perusahaan BUMD. Setiap perusahaan memiliki tanggung jawab sosial pada lingkungan sekitarnya. Hal tersebut merupakan peluang yang dapat digunakan untuk mengembangkan pariwisata Pantai Sa warna agarmenjadi lebih baik dan dapat menarik lebih banyak pengunjung. Informasi ini disampaikan agar para pelaku usaha di sekitar Pantai Sa wa rna mengetahui peran dari perusahaan-perusahaan yang a da di wila yahnya.

\subsection{Hasil kegiatan}

Kegiatan diha diri oleh tiga bela s peserta yang terdiri a tas para pemilik usa ha homestay yangjuga memiliki usaha pendukung, seperti usaha warung makan dan wa rung sembako. Hal tersebut tampak pada Gambar 2 berikut

ini.

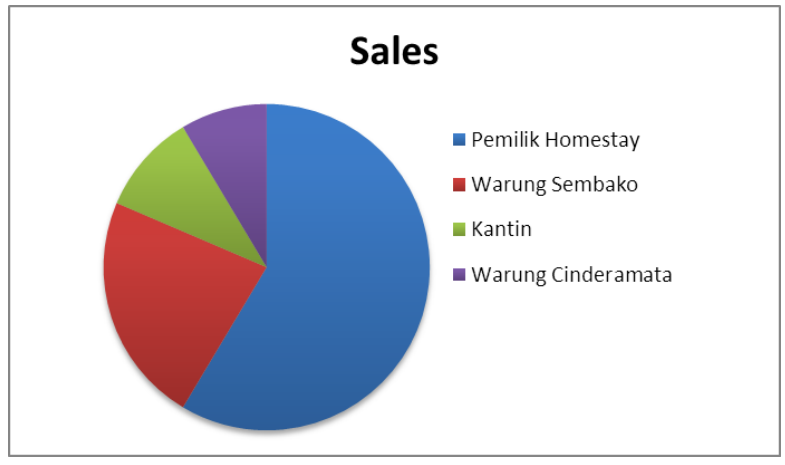

Gambar 2 Peserta pelatihan 
Informasi terkait pemanfaatan programCorporate SocialResponsibility perusahaan diterima dengan baik oleh peserta. Hal itu ditandai dengan respons positif peserta, baik selama kegiatan berlangsung maupun setelah kegiatan. Secara garis besar, hasil kegiatan pemberdayaan masyarakat dalam memanfaatkan progra m CSR perusahaan di sekitar Pantai Sawarna.

Tabel 3 Target capaian berdasarkan tahapan kegiatan

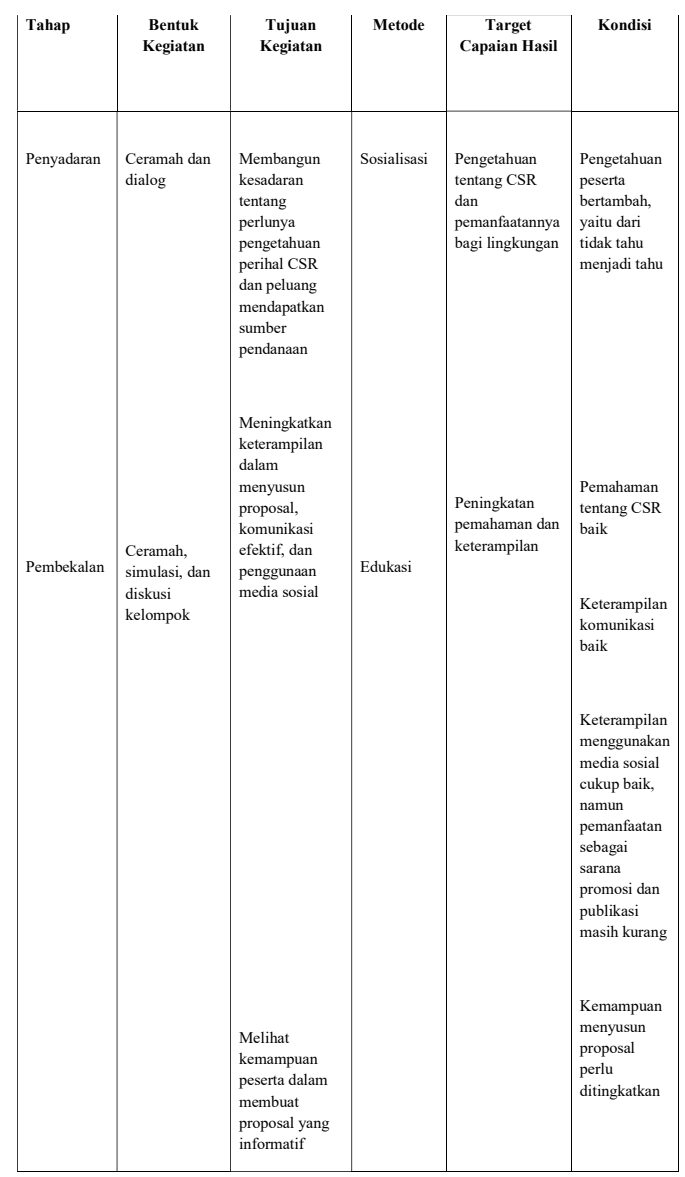

Berdasarkan Tabel 3 diketahui bahwa peserta menyadari kehadiran perusahaan-perusahaan besar yang memiliki tanggung jawab terhadap lingkungan di wilayah mereka. Peserta juga memahami bahwa ma syarakat memiliki hak dan perusahaan mempunyai kewajiban untuk membangun dan membantu lingkungan sekitarnya. Peserta juga men getahuibahwa pengembangan potensi wilayah merupakan tanggung jawa b bersama, yaitu antara masyarakat, pemerintah, dan dunia usaha. Selain itu, setelah pelaksanaan kegiatan, peserta menjadi tahu perihal CSR dan pemanfaatannya, peserta mampu melihat peluang sumber pendanaan perusahaan melalui CSR, dan peserta tertarik untuk mencoba memanfaatkannya guna mengembangkan usaha mereka sehingga dapat berkontribusi terhadap pengembangan potensi wila ya hnya meskipun secara tidak la ngsung.

Setelah pelaksanaan kegiatan, peserta menjadi paham tentang cara membuat proposal pendanaan dan tahapannya. Metode simulasi yang diterapkan dalam kegiatan memberikan pengalaman bagi peserta, yakni membuat proposal secara berkelompok meskipun memerlukan waktu lebih lama untuk dapat menyajikannya secara informatif. Peserta menyukai simula si yang dilakukan, terutama pada saat bertukar peran da lam praktik komunikasi, yaitu peran sebagai pemilik usa ha dan sebagai pengunjung serta pada saat berlatih menggunakan komunikasi efektif, baik lisan maupun tulisan.

Saat pelaksanaan kegiatan, peserta bersungguhsungguh dalam menyimak materi yang disampaikan oleh pembicara sehingga tercipta suasana kondusif dan komunikatif. Suasana tersebut membuat diskusi dapat berjalan dua arah. Peserta berani menyampaikan kendala dan permasalahan yang dialami dalam mengelola usaha homestay dan usaha pendukungnya. Ma salah lain yang disa mpaikan adalah perihal sepinya pengunjung, dan praktik calo yang membuat persaingan tidak sehat. Peserta juga tidak ragu menanyakan solusi yang bisa dilakukan untuk mengembangkan usahanya.

Hasil evaluasi pelatihan yang terkait dengan pengetahuan, pemahaman, dan kemampuan peserta tentang CSR serta pemanfaatannyaterlihat pada tabel 4 bahwa peserta memiliki pengetahuan yang baik, nilai rata-rata $43(73.5 \%)$, pemahaman dengan nilai rata-rata baik, yaitu 52 (75.5\%), dan nilai rata-rata kemampuan secara umum yang baik, yaitu (78.1\%). Akan tetapi, pada simulasi menyusun proposal pendanaan program CSR, peserta masih memerlukan pendampingan dalam mengemas pesan secara informatif. Dengan demikian, target kegiatan ini tercapai. Hal itu terlihat dari pengetahuan dan pemahaman yang diperoleh peserta dengan baik, keterampilan berkomunikasi dan penggunaan media sosial yang baik, serta kemampuan peserta dalam menyusun proposal yang cukup baik.

Tabel 4 Pengetahuan, Pemahaman, dan Kemampuan Peserta

\begin{tabular}{|c|l|c|c|}
\hline No. & \multicolumn{1}{|c|}{ Keterangan } & Skor & Persentase \\
\hline 1. & Pengetahuan & 43 & $73.5 \%$ \\
\hline 2. & Pemahaman & 52 & $75.5 \%$ \\
\hline 3. & Kemampuan & 50 & $78.1 \%$ \\
\hline
\end{tabular}


Berdasarkan evaluasi terhadap materi pelatihan, kompetensi narasumber, dan ketepatan metode yang digunakan, penyelenggaraan kegiatan pengabdian kepa da masyarakat ini secara keseluruhan mendapat penilaian sangat baik.

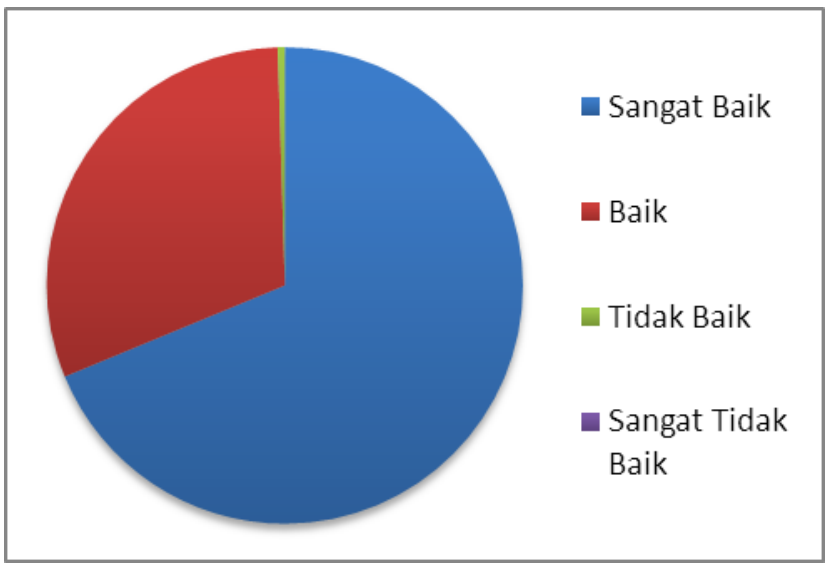

Gambar 3 Evaluasi penyelenggaraan kegiatan

Peserta menilai bahwa materi pelatihan sudah sesuai dengan kebutuhan mereka, mudah dipahami, menarik, dan in formatif. Narasumber dinilai menguasai materi, mampu membangun suasana kondusif, dan terbuka. Metode yang digunakan juga menarik, konsultatif, dan mudah untuk diterapkan. Hal ini menunjukkan bahwa pelatihan dapat memberikan manfaat bagi peserta untuk meningkatkan kemampuan pengelolaan usaha.

Kegiatan perekonomian di wilayah pesisir wisata Pantai Sawarna mulai berkembang dengan adanya aktivitas kepariwisataan yang menumbuhkan peluang usaha. Hal ini terlihat dengan adanya para penjual cendera mata dari kalangan masyarakat setempat. Rumah wa rga yang banyak dijadikan seba gai rumah singgah (homestay) bagi para turis juga menjadi bukti bahwa pembinaan mengenai kegiatan pariwisa ta bagi warga setempat telah dilakukan. Sederhana, tetapi nyaman menjadi cirikhas homestay di Pantai Sawama. Homestay juga terlihat apik, bersih, dan terjaga. Para pemiliknya yang berbahasa Indonesia dengan logat khas masyarakat Sunda bersikap ramah kepada para tamu. Hal-hal tersebut menjadi kekuatan yang dapat menarik wisatawan untuk datang kembali dan merasakan keramahan khas orang-orang Pantai Sa warna, Lebak Banten.

Ma syarakat pelaku usaha memiliki ha rapan besar untuk mendapatkan kesempatan guna mengembangkan usahanya di sektor industri pariwisata; menambah pengetahuan dalam tata kelola; meningkatkan kualitas produk dan jasa, diversifikasi, serta promosi pemasaran; dan memperoleh kemudahan dalam mengakses peluang-peluang pendanaan program CSR. Oleh karena itu, keberlanjutan program diarahkan pada kegiatan pendampingan. Melalui kerja sama antara perguruan tinggi, ma syarakat, pemerintah, dan dunia usaha, program pemberdayaan masyarakat akan bermanfaat lebih lua s bagi masyarakat.

\section{KESIMPULAN}

Sosia lisa si pemanfaatan program CSR perusahaan bagi pelaku usaha di sekitar Pantai Sawarna memperoleh hasil baik dan memenuhi target capaian. Peserta mendapatkan pengetahuan dan pemahaman yang baik, keterampilan berkomunikasi dan menggunakan media sosialyang baik, serta kemampuan menyusun proposal yang cukup baik. Materi pelatihan dan metode yang digunakan menunjukkan bahwa pelatihan dapat memberikan manfaat bagipeserta untuk meningkatkan kemampuan dalam mengelola usahanya.

Hasil kegiatan menujukkan bahwa peserta memerlukan tindak lanjut dalam implementasi pengajuan permohonan dana CSR kepada perusahaan sekitar serta memerlukan kemudahan akses ke perusahaan dan birokrasi pemerintah. Oleh karena itu, keberlanjutan program pengabdian kepada masyarakat diarahkan pada kegiatan pendampingan untuk meningkatkan kemampuan dan keterampilan dalam mengomunikasikan pesan secara informatif dan efektif sebagai upaya memanfaatkan program CSR perusahaan.

\section{UCAPAN TERIMAKASIH}

Apresiasi dan terima kasih kepada Pusat Pengabdian Kepada Masyarakat, Direktur Riset dan Teknologi, Publikasi dan Kerjasama Domestik Universitas Mercu Buana yang telah mendanai dan memfasilitasi kegia tan ini hingga selesai. Kami juga menghaturkan terima kasih kepada Kelompok Sadar Wisata (POKDARWIS) Desa Sawarna sebagai mitra kerjasama dalam penyelenggaraan kegiatan, para peserta kegiatan dan pihak-pihak yang telah membantu, menyumbangkan pikiran dan tenaga untuk merea lisasikan kegiatan pengabdian ini.

\section{DAFTAR PUSTAKA}

Akda, G., \& Öter, Z. (2011). Assessment of world tourism from a geographical perspective and a comparative view of leading destinations in the market. In Procedia - Social and Behavioral Sciences. https://doi.org/10.1016/j.sbspro.2011.05.126

Atkinson, D. (2016). Is South Africa's Great Karoo region becoming a tourism destination? Joumal of Arid Environments. https://doi.org/10.1016/j.jaridenv.2015.12.006

Badan Pusat Statistik Kabupaten Lebak. (2018). Kecamatan Bayah DalamAngka. Retrieved from https://lebakkab.bps.go.id/publication/download .html?

Biddulph, R. (2015). Limits to mass tourism's effects in rural peripheries. Annals of Tourism Research. https://doi.org/10.1016/j.annals.2014.11.011 
Dina s Pariwisata Provinsi Banten. (2017). Penyusunan Rencana Induk Kawasan Strategis Pariwisata (KSP) Provinsi Banten Desa Wisata Sawama. Dinas Pariwisata Provinsi Banten. Retrieved from

https://dmsppid.bantenprov.go.id/upload/dms/4 7/laporan-akhir-desa-sawarna.pdf

Fatimah, T. (2015). The Impacts of Rural Tounism Initia tives on Cultural Landscape Sustainability in Borobudur Area. Procedia Environmental Sciences.

https://doi.org/10.1016/j.proenv.2015.07.067

Ife, J., \& Tesoriero, F. (2006). Community Development: Community-based a lternatives in an a ge of globalisation (3rd editio). Australia: French's Forest: Pearson Education.

Irawan, E. P. (2018). The Disclosure of Corporate SocialResponsibility Motives: In the Socio Digi Leaders Program for Young Generation Indonesia. International Journal of Current Research, 10(11), 75833-75839. https://doi.org/DOI:

https://doi.org/10.24941/ijcr.33350.11.2018

Kabar Banten. (2018, April 11). Isu Tsunami Ga galkan Rombongan Wisatawan ke Sawarna. Kabar Banten.Com.

Liputan 6. (2018). Usai Gempa Bumi, Pantai Sawama Sepi Pengunjung. Liputan6.Com.

Obonyo, G. O., \& Fwaya, E. V. O. (2014). Integrating Tourism with rural development strategies in western Kenya. Citizen Participation in Decision Making: Towards Inclusive Development in Kenya, (December), 160-173. https://doi.org/10.2307/j.ctvk8w097.16

PPID Provinsi Banten. (n.d.). Daftar Perusahaan Badan Usaha Milik Daerah (BUMD) di LingkunganProvinsi Banten. Retrieved November 9, 2020, from https://bpbd.bantenprov.go.id/upload/deni/foto/ Daftar BUMD Provinsi Banten.pdf

Rahma, R. Y., Yuliawati, E., \& Gusfa, H. (2017). Pemanfaatan Media Sosial oleh Remaja sebagai Sarana Promosi Wisata Pantai Sawarna dI Kecamatan Bayah, Kabupaten Lebak, Banten. Pusat Penelitian, Universitas Mercu Buana.

Rahmatullah. (2011). CSR dan Kepentingan Pemerintah Da erah. Lab.Ane.Fisip.Untirta.Ac.Id.

Sulistiyani, A. T., Aisyah, D., Mamat, I., \& Sontang, M. (2016). Pemberdayaan Masyarakat Pemanfaatan Limbah Tulang Ikan untuk Produk Hidroksiapatit (Hydroxyapatite/HA) Kajian di Pabrik Pengolahan Kerupuk Lekor Kuala Terengganu-Malaysia. Jurnal Pengabdian Kepada Masyarakat (Indonesian Journal of Community Engagement), 2(1), 14-29. https://doi.org/10.22146/jpkm.22086

Sulistyani, A. T., \& Wulandari, Y. (2017). Proses Pemberdayaan Masyarakat Desa Sitimulyo Kecamatan Piyungan Kabupaten Bantul Dalam Pembentukan Kelompok Pengelola Sampah Mandiri (KPSM). Jurnal Pengabdian Kepada
Masyarakat (Indonesian Journal of Community Engagement), 2(2), 146-162. https://doi.org/10.22146/jpkm.27024

Susilowa ti, M. H. D. (2017). Potensi Wilayah Sekitar Pantai Selatan Kabupaten Lebak Provinsi Banten Dalam Mendukung Pembangunan Pariwisata, 105-111. Retrieved from http://journal2.um.ac.id/index.php/jpg/article/vi ew/1001/573

Tim Pikiran Rakyat. (2019). Masih Tra uma Tsunami, Kunjungan ke Pantai Turun 60 Persen. Pikiran Rakyat.Com. Retrieved from https://www.pikiran-rakyat.com/nasional/pr01313729/masih-trauma-tsunami-kunjunganke-pantai-turun-60-persen

Unda ng-Undang No. 40 Tahun 2007 Tentang Perseroan Terbatas. (n.d.). Retrieved from https://www.ojk.go.id/sustainablefina nce/id/peraturan/undangundang/Pages/Undang-Undang-No.-40-tahun2007-tentang-Perseroan-Terbatas.aspx

Undang-Undang Republik Indonesia Nomor 10.Tahun 2009 Tentang Kepariwisataan. (n.d.). Retrieved from

https://www.kemenparekraf.go.id/asset_admin/a ssets/uploads/media/old_file/4636_1364UUTentangKepariwisa taannetl.pdf

Vita surya, V.R.(2016). Local Wisdom for Sustainable Development of Rural Tourism, Case on Ka libiru and Lopati Village, Province of Daerah Istimewa Yogyakarta. Procedia - Social and Behavioral Sciences, 216(October 2015), 97108. https://doi.org/10.1016/j.sbspro.2015.12.014

Zaidan, E. (2016). The impact of cultural distance on local residents perception of tourism development: The case of Dubai in UAE. Tourism. Retrieved from https://www.semanticscholar.org/paper/Theimpact-of-cultural-distance-on-local-residentsZaidan/c9ac787f0e5c101197d8d3bb1dc9aa15e1 $3 \mathrm{db} 19 \mathrm{f}$

Zakaria, F., \& Suprihardjo, D. (2014). Konsep Pengembangan Kawasan Desa Wisata di Desa Bandungan Kecamatan Pakong Kabupaten Pa mekasan. Teknik Pomits. https://doi.org/23373520 